УДК 351.86:343.326] $(477+100)$

DOI https://doi.org/10.32849/2663-5313/2019.10.38

\title{
олександр Жайворонок,
}

аспірант кафедри глобалістики, євроінтеграчії та управління начіональною безпекою Національної академії державного управління при Президентові України

\section{ПРИЧИНИ І ДЖЕРЕЛА ЕСКАЛАЦІї ІНФОРМАЦЙНОГО ТЕРОРИЗМУ В УКРАÏHI ТА СВITI}

У статті проаналізовано причини виникнення, розвитку та поширення тероризму, а також його сучасного й актуального різновиду - інформаиійного тероризму - у світі та в Украӥні через призму геополітичних чинників, зумовлених конфліктом політичних і економічних інтересів держав. Даний аналіз $\epsilon$ важливим у дослідженні тероризму, оскільки ие допомагає зрозуміти природу, передумови терористичного конфлікту та його міжнародно-правову форму. Автор доводить, що міжнародний тероризм ие певний соиіальний процес, який розгортається в просторі та часі і пов'язаний із геополітичними, геоекономічними та сочіально-економічними факторами, ефективність боротьби з яким характеризу ється наявністю дієвих міжнародних правових основ та об'єднанням зусиль світового співтовариства.

Проведено аналіз наукових досліджень сучасного інформачійного тероризму провідних вітчизняних і світових науковиів в аспектах історії розвитку тероризму, загальночивілізачійних прочесів, проблем правового регулювання інформачійного тероризму, розробки кониепиій реагування органів влади на терористичну діяльність, а також із кримінально-правових позичій.

Визначено риси сочіального конфлікту, що породжує інформаційний тероризм, та сформовано його основні ознаки. Досліджено історіографію проблеми, особливо в аспекті розуміння інформаиійно20 тероризму як соціального конфлікту, що має певні етапи розвитку та поширення залежно від його розгортання у конкретній крайні за такими ознаками: соціальний тероризм, економічний тероризм, політичний тероризм, державний тероризм, ідеологічний тероризм, міжнародний тероризм.

Зроблено висновок про те, що боротися з таким явищем, як інформаиійний тероризм (нерідко на міжнародному, регіональному чи міждержавному просторі), $i$ запобігти йому може тільки міжнародна співпраия всіх держав у сфері міжнародної інформаиійної безпеки, яка на основі збалансованих міжнародних нормативно-правових актів з урахуванням спещифіки національних законодавств та наявності політичної волі держав зможе забезпечити створення ефективної системи міжнародної інформаційної безпеки.

Ключові слова: глобалізація, ескалація тероризму, світовий порядок, міжнародне право, міжнародний тероризм.

Постановка проблеми. Сучасний тероризм дедалі більше набуває катастрофічного характеру, загрожує стабільності цілих народів, а тому вимагає рішучих заходів держав і світового співтовариства, що можуть привести до зниження цієї загрози. Результативність боротьби з тероризмом залежить, зокрема, від створення ефективних правових основ протидії цьому явищу.

Цілі, методи і засоби сучасного тероризму є дуже різноманітними, їх можна класифікувати за різними критеріями, але зазвичай дані категорії пов'язані між собою і з тими результатами, яких намагаються досягти терористи. Еволюціонувавши за останні роки, цілі, методи і засоби тероризму перетворили цей злочин на одну із найсерйозніших загроз для життєво важливих інтересів суспільства, держав та міжнародного співтовариства у цілому.
Ці обставини й визначили зв'язок загальної проблеми з найбільш важливими науковими та практичними завданнями аналізу сучасного стану інформаційного тероризму у світі і в Україні, а також зумовили необхідність визначення причин і умов ескалації цього злочинного міжнародного явища 3 метою пошуку і запровадження дієвого міжнародно-правового механізму боротьби 3 ним.

Аналіз останніх досліджень і публікацій. Проведення аналізу сучасних проявів інформаційного тероризму в Україні й у світі, а також причин і джерел їх створення показало, що натепер існує безліч наукових досліджень із цієї тематики. Серед них слід згадати праці Г. Веймана, П. Вілкінсона, У. Лакера, Б. Накос, Ф. Перла, Б. Хофмана, Р. Шафферта, А. Шміда та ін., які здійснили чимало напрацювань за тематикою політич- 
ного аспекту тероризму і його інформаційного складника зокрема. Варто також назвати роботи вчених, які певною мірою досліджували проблеми екстремізму та тероризму в контексті загальноцивілізаційних процесів: Д. Белла, Ж. Бодрійара, Е. Гіденса, М. Кастельса, Дж. Лалла, К. Поппера, Е. Тоффлера, Ф. Фукуяму, С. Хантінгтона та ін.

Окремі аспекти проблеми правового регулювання інформаційного тероризму розглядались у працях В. О. Васеніна, В.Д.Недільніченко, М. Герке, А. В.Крутських, А. Д. Слякова, Р. А. Шаряпова, Ш. Шольберга, М. Дюмонтьє та Дж. Бірда. Питання використання терористами ЗМІ досліджувались О. Л. Вартановою, методологічні проблеми протидії інформаційному тероризму висвітлено в роботах В. В. Ященко та А. А. Сальникова. Проте малодослідженим залишилось питання міжнародно-правового регулювання інформаційного тероризму і комплексного аналізу нормативних документів міжнародних організацій та наявних теоретичних концепцій, присвячених цій проблемі.

Причини, мотиви, механізми і психологію здійснення терористичних актів досліджують С. Акуавіва, А. Минуччі, Л. Стортоні, Ж. Пакуіно, А. Сиідж, Г. Деникер, Р. Соле, Й. Беккер, Є. Анчел, У. Лакер, В. Уддіс, Ч. Паркін. У своїх роботах вони пропонують фундамент для практичної боротьби з тероризмом, розробки концепцій реагування органів влади на терористичну діяльність.

В Україні серед досліджень із цієї проблеми слід відзначити роботи В. Антипенка, Т. Бояр-Созановича, В. Глушкова, В. Смельянова, В. Тихого, що містять розробку кримінально-правового аспекту тероризму та аналіз норм про відповідальність за тероризм в українському законодавстві. Теоретичним та методологічним розробкам щодо вивчення історії розвитку тероризму, основних тенденцій його еволюції присвячено дослідження О. Будницького, К. Жаринова, В. Замкового, М. Ільчикова, А. Суворова, М. Требіна та інших вчених.

Останніми роками 3'явилися наукові дослідження, в яких тероризм розглядається як особливий вид злочину, а саме з кримінально-правових позицій. Найбільш грунтовні розробки було здійснено такими науковцями, як В. Антипенко, Ю. Антонян, В. Свдокимов, В. Смельянов, В. Комісаров, В. Крутов, Н. Литвинов, В. Ліпкан, В. Лунєєв, Є. Ляхов, Д. Нікіфорчук, М. Руденко, К. Салімов.

У межах наступного напряму можливо виділити роботи, присвячені аналізу політичного тероризму. Зазначену тему активно розробляли Ю. Авдєєв, О. Бардін, Я. Дашкевич, В. Епштейн, Н. Лазарєв, Л. Мошкова, С. Телешун, А. Яцько та ін.

Мета статті є пошук та здійснення аналізу причин, а також дослідження джерел ескалації інформаційного тероризму в Україні та світі, доведення тези про те, що міжнародний тероризм - це не просто злочин проти людства, а сформований соціальний процес, пов'язаний із геополітичними, геоекономічними та соціальноекономічними факторами, боротьба з яким перш за все повинна грунтуватися на запровадженні дієвих міжнародних правових основ у цій сфері.

Виклад основного матеріалу. Причини тероризму полягають у поглиблені кризових явищ, нездатності суспільства регулювати складні соціально-політичні процеси, швидкій зміні систем політичних ідеалів та моральних цінностей, залученні до активного політичного життя широких верств населення, позбавлених політичного досвіду. У результаті активізується прагнення використати слабкості суспільної та політичної системи та досягнути поставленої мети «найкоротшим» шляхом за допомогою насильства та терору [1, с. 373]. У світі сучасного технологічного суспільства (електронної торгівлі, новітніх технологій у виробництві, медицині, освіті, науці та інших галузях) особливої актуальності набувають і нові (інформаційні) прояви терористичного характеру. Мережа Інтернет для скоєння терористичних акцій використовується як засіб комунікації терористичних організацій, вербування послідовників, поширення відповідної літератури та залякування людей шляхом трансляцій актів насилля.

Упродовж усієї історії іррегулярність терористичних методів боротьби зумовлювалась конфліктам політичних i економічних інтересів держав, різницею у їх військово-економічному потенціалі. Перехід світоустрою від двополярної основи до багатополярного світу різко посилив дію конфліктогенних чинників у всіх без винятку важливих сферах відносин держав i націй, соціальних, політичних та економічних інститутах міжнародного співтовариства. Досвід останніх років демонструє, як за умов глобалізації світу, пошуку нових конфігурацій світоустрою загострилася боротьба за статус та ресурси, права та впливи різних міжнародних соціальних суб'єктів: міждержавних утворень, держав, народів, суспільних рухів, конфесій, транснаціональних компаній. У цьому аспекті інформаційний тероризм має 
транснаціональний характер, а його наслідки можуть поширюватись на території одразу кількох держав.

У зв'язку з відсутністю загальновизнаного конвенційного визначення тероризму та наявності багатьох його доктринальних понять, які не містять вичерпних ознак тероризму, слід звертатися до витоків, причин та умов тероризму, розглядати його не як одноразовий акт, а як певний процес, що розгортається в просторі та часі і пов'язаний iз геополітичними, геоекономічними та соціально-економічними факторами, що впливають на його появу та розвиток [3]. Так само і немає загальноприйнятого визначення інформаційного тероризму. Дослідники визначають «кібертероризм», «інформаційний тероризм» та «комп'ютерний тероризм», а до геополітичних чинників інформаційного тероризму відносять комплекс географічних, історичних, політичних та інших факторів, що високотехнологічно взаємодіють між собою і здійснюють колосальний вплив на соціальну стабільність сучасної держави.

Визначення геополітичних чинників є дуже важливим у дослідженні інформаційного тероризму, оскільки це допомагає винайти ключ до з'ясування природи, передумов цього злочину та його міжнародноправової форми. Актуальним це питання $€$ і для України, що тримає зовнішньополітичний курс на інтеграцію до європейського політичного, економічного, правового простору.

Таким чином, на нашу думку, постає необхідність забезпечення міжнародної інформаційної безпеки міжнародно-правовими документами. Міжнародне право тільки вступає на шлях її регулювання. Необхідно створити міжнародно-правові механізми протидії інформаційному тероризму, а також розробити та реалізувати правові заходи забезпечення безпеки в інформаційному просторі, а саме:

- обгрунтувати протидію інформаційному тероризму як основоположну ідею міжнародного права;

- з'ясувати аспекти міжнародно-правового статусу кіберзлочинних терористичних організацій;

- розробити єдину систему боротьби 3 інформаційним тероризмом на міжнародно-правових засадах;

- розробити цілий ряд загальноприйнятих міжнародних дефініцій понять «інформаційний тероризм», «протидія інформаційному тероризму», «запобігання інформаційному тероризму в сучасному міжнародному праві», «механізм міжнародно-правової протидії інформаційному тероризму»;
- обгрунтувати і закріпити на міжнародному рівні (наприклад, на рівні країн-членів ООН) концепцію запровадження відповідальності держав за міжнародні правопорушення у сфері протидії інформаційному тероризму

Чіткі ознаки тероризму, що має в собі геополітичний фактор, містить також поняття «державний тероризм». Науковець В. В. Лунеев визначає його як терористичну діяльність самої держави проти внутрішніх політичних супротивників або проти іноземних держав для вирішення внутрішньополітичних та зовнішньополітичних задач. У Резолюції Генеральної асамблеї ООН 39/159 1984 р. «Про недопущення політики державного тероризму та будь-яких дій держав, спрямованих на підрив суспільно-політичного устрою в інших суверенних державах» така діяльність отримала міжнародне засудження [4].

Сучасний світовий порядок можна охарактеризувати як економічний порядок або "Pax Oeconomicana", в якому успішно паразитує тероризм. Таке поняття використовує А. I. Неклесса у своїх працях. Рах Oeconomicana - це сучасний світопорядок, де силові маневри епохи вже не пов'язані ні iз завоюванням територій, ні навіть 3 прямим підпорядкуванням економічного простору супротивника. Вони швидше націлені на нав'язування оточенню своєї політичної волі і бачення майбутнього, на встановлення і підтримання бажаної типології світогосподарських зв'язків, на досягнення стратегічних горизонтів, які визначаються геоекономічною конкуренцією i масштабним управлінням ризиками, на зміцнення чи підрив тієї чи іншої системи соціальноекономічних орієнтацій [7, с. 230]. I хоча A. I. Неклесса, як російський політолог і економіст, член експертних рад при Держдумі Російської Федерації, обгрунтовуючи свої думки, перш за все ототожнює їх із Західним світом (наприклад, із США), ті ж самі підходи можна застосувати і до Російської Федерації, що здійснює політику країниагресора проти України. Так, починаючи з 2000-х років на території України Росія вела масштабну антиукраїнську та антизахідну пропаганду, основою якої стала доктрина «русского мира».

У часи фінансовоїцивілізації відбувається заміна публічно обраних політиків на представників влади, обраних фінансовою елітою. Сучасна глобальна економіка включає такі види, як квазіекономіка, параекономіка та віртуальна економіка. Квазіекономіка являє собою ведення нелегальної еконо- 
міки, до якої належать виробництва і розповсюдження наркотиків, великомасштабні розкрадання, рекет, контрабанда, корупція казнокрадство, комп'ютерні афери, торгівля людьми, дешеве поховання токсичних відходів, відмивання «брудних» і виробництво фальшивих грошей, комерційний тероризм. Головним ресурсом деструктивної параекономіки є багатство цивілізації, вона розповсюджує заборонені види економічної практики та їх індустріалізацію на основі сучасних кримінально-терористичних технологій. «Трофейна економіка» паразитує на досягненнях цивілізованої економіки і користується її плодами [7].

Віртуальна економіка проявляється в шантажах, шуллерствах на фондових біржах, продажах акцій, тобто операціях, які мають на меті прибуток, а не вироблення реальної вартості, яка, враховуючи насичення ринку «суспільства споживання», покликана служити в основному цілям забезпечення бідних регіонів. У цій системі латентного обкрадання криється механізм перешкоджання розвитку економічно слаборозвинених країн. Водночас помітне зростання i концентрація багатства на іншому полюсі породжує терористичні акти. Це пов'язане з тим, що розвиток глобальної економіки залишає бідні країни без надії на такий самий розвиток. Погіршується становище тим, що такі процеси не криміналізовані [8, с. 107].

Конфліктогенність наявного комплексу економічних суперечностей визначається трьома основними характеристиками. По-перше, вони породжують протестні настрої і відповідні найрізноманітніші наміри, по-друге, конфліктне, нестабільне середовище саме по собі є умовою, що сприяє багаторазовому зростанню прибутків для великого транснаціонального капіталу, і особливо для зазначених форм квазіекономіки, а по-третє, створення обстановки нестабільності та конфліктності в регіонах використовується 3 метою обгрунтування економічної і політичної неспроможності національних режимів [9].

Такий характер ворожості сторін у терористичному конфлікті, що розвивається в сучасних економічних умовах світопорядку, призводить до асиметричності терористичних актів. Поняття асиметричності терористичних актів передбачає засіб боротьби, що застосовується бідною більшістю, яка опинилася за межами сучасного технологічного розвитку, з метою усунення глобального соціально-економічного розриву у розвитку. Такими засобами можуть бути захоплення в заручники заможної меншості або більш радикальні способи, але їх головною умовою $€$ висунення міжнародному співтовариству ультиматуму, гіршою альтернативою якого вбачається можливість катастрофічного варіанту [2, с. 25].

Тероризм як соціальний конфлікт виступає також предметом вивчення соціології, яка визначає та досліджує соціальні передумови його виникнення.

На думку соціолога Ернста Аречаги, тероризмом $є$ акти, що мають традиційні форми загальнокарних злочинів, але вчинених навмисно, з метою викликати паніку, безладдя в організованому суспільстві, зруйнувати суспільний порядок, паралізувати протидію терору з боку суспільних сил й інтенсифікувати лиха і страждання суспільства. Соціолог Юджин Дінстейн (Ізраїль) стверджує, що суть тероризму взагалі й міжнародного зокрема виявляється в безладному насильстві, спрямованому проти людей, не перебираючи (безневинні жертви терористичного акту), 3 метою створення в масах ідеї, що мета виправдовує засоби: чим жахливіший злочин, тим краще, з погляду терористів [6].

На думку професора О. С. Онищенко, соціальному протистоянню всередині держави сприяють такі чинники: деформація середнього класу, маргіналізація певних верств суспільства, влада олігархії, пропаганда федералістських та сепаратистських ідей, втрата незалежності вітчизняного інформаційного простору, руйнування вітчизняного науково-освітнього, культурного, технічного та технологічного простору i, нарешті, загроза моральних деформацій у суспільстві у вигляді поширення морального, правового та культурного нігілізму [10].

Такі протистояннявідбуваються не лише в середині кожної держави, а й у світі. Соціально-економічні та міжцивілізаційні протистояння характерні для сучасного світопорядку, де протистояння між розвинутою північчю та бідним півднем, бідним та багатим населенням, народами постійно зростає. Така маргіналізація світу призводить лише до маргінального екстремізму та міжнародного тероризму. Тому Ю. Антонян, і О. Будницький абсолютно справедливо акцентують увагу на зв'язку психологічних мотивацій тероризму зі специфічним станом суспільно-економічних та суспільно-політичних взаємин [11].

Отже, можна констатувати, що характерною рисою сучасного інформаційного тероризму, як соціального конфлікту, $€$ насамперед публічність, забезпечення якої покладається на традиційні мас-медіа (пресу, 
радіо, телебачення) й Інтернет-медіа. Технологічний прогрес і розвиток засобів масової комунікації вимагають переосмислення значення ролі ЗМІ в суспільстві, усвідомлення значимості характеру, форм і методів подачі інформації для управління суспільною свідомістю. Сучасний інформаційний тероризм із настанням епохи інформаційного суспільства перейшов у якісно нову стадію - ведення інформаційно-психологічних війн, створюючи інформаційний привид жаху й хаосу.

На основі порівняльного аналізу наукової літератури, міжнародних документів та кримінального законодавства різних держав В. П. Смельянов визначає чотири специфічні ознаки тероризму: 1) породження реальної загальної небезпеки, спричиненої загальнонебезпечними діяннями або їх загрозою; 2) публічний характер тероризму; 3) умисне створення стану страху, пригніченості, напруги; 4) під час здійснення терористичного акту загальнонебезпечне насилля застосовується щодо одних осіб або майна, а психологічний вплив з метою схилення до певної поведінки спрямовується на інших. Враховуючи ці ознаки, В. П. Смельянов надає узагальнене визначення тероризму як такого, що є загальнонебезпечними діяннями або загрозами, які здійснюються публічно та спрямовані на залякування населення або соціальних груп 3 метою прямого або побічного впливу на прийняття будь-якого рішення або відмову від нього в інтересах терористів [13].

Деякі науковці визначають кожний чинник тероризму як окремий етап його ескалації в окремо взятій країні та форми, в яких виражається кожний чинник. Такий розвиток тероризму складається із шести етапів:

1. Соціальний тероризм: руйнація соціальних підвалин, викрадення людей, вивіз та сексуальна експлуатація жінок, бандитизм, рекет, утримання у рабстві;

2. Економічний тероризм: підрив основ економіки, корумпованість влади, фінансові шахрайства, розкрадання бюджетних коштів;

3. Політичний тероризм: політична дестабілізація, сепаратизм, націоналізм;

4. Державний тероризм: руйнування економіки, піратські зони, локальні війни, бандитські вторгнення;

5. Ідеологічний тероризм: інформаційний терор, релігійна експансія, деідеологізація;

6. Міжнародний тероризм: руйнація міжнародних відносин, відміна кредитів, припинення транспортування нафтопродуктів, імпортно-експортне ембарго, позбавлення інвестицій.

На кожному етапі розвитку тероризму відбувається відповідне нарощування фінансових ресурсів. Кошти, одержані від однієї сфери злочинного бізнесу, дають змогу вчинювати інші, більш складні злочини, у тому числі ті, які виходять далеко за межі держави. Аналіз динаміки такого процесу свідчить, що базові фінансові ресурси було одержано на двох перших рівнях деструкції: під час руйнації соціальних підвалин та підриву економіки. Такий аналіз свідчить про те, що тероризм як конфлікт складається із взаємопов'язаних чинників, які зумовлюють його розвиток, та має досліджуватися з точки зору всіх його чинників [9].

\section{Висновки}

Підсумовуючи вищезазначене, можна зробити висновок про те, що поняття міжнародного тероризму досі не має єдиного офіційного й загальноприйнятого визначення, проте однозначно, розробляючи визначення, необхідно виходити з походження слова, яке аргументує основні цілі тероризму - залякування, створення атмосфери страху і невпевненості, а також мати на увазі, що даний злочин містить у своєму складі широке коло діянь, тому важко конкретно вказати, які саме ситуації необхідно буде трактувати як міжнародний тероризм. До того ж не можна не віднести до кола суб'єктів злочину розвинуті держави, які своєю політикою утворюють передумови для застосування такого радикального методу боротьби, як терористичні акти з боку іншої сторони.

Цілі, методи і засоби сучасного інформаційного тероризму є дуже різноманітними, їх можна класифікувати за різними критеріями, але зазвичай дані категорії пов'язані між собою і з тими результатами, яких намагаються досягти терористи. Еволюціонувавши за останні роки, цілі, методи і засоби тероризму перетворили цей злочин на одну із найсерйозніших загроз для життєво важливих інтересів суспільства, держав та міжнародного співтовариства в цілому.

Ці фактори й визначають предмет подальших досліджень цього вкрай небезпечного міжнародного злочину. До того ж необхідно особливу увагу приділити дослідженням видів тероризму, особливо такого його актуального для сучасного технологічного суспільства різновиду, як інформаційний тероризм.

Запобігти цьому може тільки міжнародна співпраця всіх держав у сфері міжнародної інформаційної безпеки, яка на основі збалансованих міжнародних нормативно-правових актів з урахуванням специфіки національних законодавств та наявності політичної волі держав зможе забезпечити створення ефективної системи міжнародної інформаційної безпеки. 


\section{Список використаних джерел:}

1. Антипенко В. Ф. Поняття тероризму. Право Украӥни. 1999. № 2. С. 92

2. Антипенко В.Ф. Борьба с современным терроризмом: международно-правовые подходи : монография. Киев : Национальная библиотека В.И. Вернадского; Изд-во «Юнона - М», 2002. С. 7

3. Антипенко В.Ф. Современный терроризм: состояние и возможности его упреждения (криминологическое исследование). Киев : НБУВ, 1998. 190 с.

4. Протокол о запрещении применения на войне удушающих, ядовитых или других подобных газов и бактериологических средств, Женева, 17 июня 1925 года / Верховна Рада України. URL : http://zakon5.rada.gov.ua/laws show/995_198 (дата звернення: 02.09.2019).

5. Завер Гафаров. Преступления международного характера в глобализирующемся мире Москва : ОЛМА-ПРЕСС, 2006. 541 с

6. Гассер Х-П. Террористические акты, "терроризм" и международное гуманитарное право. Дискуссия по гуманитарным вопросам: право, политика, деятельность : сборник статей. Москва 2003. С. 235-236.

7. Моджорян Л.А. Терроризм и национальноосвободительные движения. Государство и право. 1998. № 3 .
8. Антипенко В.Ф. Борьба с современным терроризмом: международно-правовые подходи : монография. Киев : Национальная библиотека В.И. Вернадского; Изд-во «Юнона - М», 2002. С. 7.

9. Антонян Ю.М. Терроризм. Криминалистическое и уголовно-правовое исследование. Москва, 1998. С. 72-73.

10.Додатковий протокол до Женевських конвенцій від 12 серпня 1949 року, що стосується захисту жертв збройних конфліктів неміжнародного характеру (Протокол II), від 8 червня 1977 року. Відомості Верховної Ради України. 1977. URL : http://zakon5.rada.gov.ua/laws/ show/995 200 (дата звернення: 02.09.2019).

11. Рибачок А. Міжнародний терор і тероризм в Україні. Київ : Наукова думка, 2002. 954 с.

12. Гаазька декларація про заборону вживати кулі, що легко розвертаються або сплющуються в людському тілі : Міжнародний документ від 1899 р. / Верховна Рада України. URL : http:// zakon3.rada.gov.ua/laws/show/995_195 (дата звернення: 02.09.2019)

13. Дрёмин В.Н., Дрёмина Н.А., Зелинский C.A. Международное сотрудничество в борьбе с терроризмом. Актуальні проблеми держави $i$ права : зб. наук, праць / редкол.: С.В. Ківалов (голов, ред.) та ін. Одеса : Юрид. л-ра, 1998. 187 с.

The article analyzes the causes of the emergence, development and spread of terrorism, as well as its current and current variety - information terrorism in the world and in Ukraine through the lens of geopolitical factors caused by the conflict of political and economic interests of states. This analysis is important in the study of terrorism, since it helps to understand the nature, prerequisites of a terrorist conflict and its international legal form. The author argues that international terrorism is a certain social process that unfolds in space and time and is connected with geopolitical, geoeconomic, and social-economic factors. .

The analysis of scientific researches of modern information terrorism of leading national and world scientists on the aspects of the history of terrorism development, general civilizational processes, problems of legal regulation of information terrorism, development of concepts of reaction of authorities to terrorist activity, as well as from criminal law positions is carried out.

The features of social conflict that in forms information terrorism are identified and its main features are formed. The historiography of the problem has been investigated, especially in the aspect of understanding information terrorism as a social conflict, which has certain stages of development and distribution depending on its deployment in a particular country on the following features: social terrorism, economic terrorism, political terrorism, state terrorism, ideologism.

It is concluded that combating and preventing such phenomenon as information terrorism (often in the international, regional or interstate space) can only be a joint international cooperation of all states in the field of international information security, which, on the basis of balanced international normative legal acts, taking into account the specifics national lawes and the political will of the states will be able to ensure the establishment of an effective system of international information security.

Key words: globalization, escalation of terrorism, world order, international law, international terrorism. 